\title{
Karakteristik Pasien Tumor Trofoblas Gestasional Risiko Rendah dengan Kemoresitensi terhadap Metotreksat yang Dirawat di RSUP Dr. Hasan Sadikin Bandung Periode 2011-2015
}

\author{
Ronald Jeckson Sinaga, Maringan D.L. Tobing, Ali Budi Harsono \\ Departemen Obstetri dan Ginekologi Fakultas Kedokteran Universitas Padjadjaran \\ Rumah Sakit Dr. Hasan Sadikin Bandung \\ Korespondensi: Ronald Jeckson Sinaga,Email: ronaldjacksonsinaga@gmail.com
}

\begin{abstract}
Abstrak
Tujuan: Penelitian ini akan mendeskripsikan karakteristik pasien TTG risiko rendah yang resisten terhadap metotreksat di Rumah Sakit Hasan Sadikin Bandung selama periode 2011-2015.

Metode: Penelitian ini merupakan penelitian deskriptif retrospektif, berlokasi di Departemen Obstetri dan Ginekologi dan Instalasi Rekam Medis Rumah Sakit Hasan Sadikin Bandung dari bulan April sampai Mei 2017. Hasil: Selama periode penelitian didapatkan 46 kasus TTG risiko rendah yang resisten terhadap metotreksat. Jumlah kejadian terbanyak pada rentang usia 31-35 tahun (45,6\%), 36,9\% dengan paritas 2, 69,6\% dengan gejala klinis perdarahan vagina abnormal, 91,3\% dengan kehamilan sebelumnya mola hidatidosa, 52,5\% kasus memiliki interval antara kehamilan dengan diagnosis TTG $\leq 4$ bulan, 60,9\% kasus kadar $\beta$-hCG awal $>100.000 \mathrm{mIU} / \mathrm{ml}$. Sebanyak 28,3\% kasus bermetastasis, 76,9\% di paru-paru dan 23\% di otak. Sebagian besar kasus TTG ditemukan pada stadium I (65,2\%) pada tahap II, III dan IV adalah 10,9\%, 15,2\% dan 8,7\%.

Diskusi: Resistensi terhadap metotreksat pada kasus TTG risiko rendah kebanyakan terjadi pada pasien berusia 31-35 tahun, paritas 2, gejala klinis perdarahan vagina abnormal, kehamilan sebelumnya mola hidatidosa, interval antara kehamilan sebelumnya dengan saat didiagnosis TTG $\leq 4$ bulan, $\beta$-hCG awal $>100.000 \mathrm{mIU} / \mathrm{ml}$, dan paling banyak ditemukan pada stadium I.
\end{abstract}

Kata kunci: Tumor trofoblas gestasional risiko rendah, kemoresisten

\section{Characteristic of Low Risk Gestational Thropoblastic Neoplasia Patien with Chemoresistance to Methotrexate at Dr. Hasan Sadikin General Hospital Bandung in 2011-2015}

\begin{abstract}
Objecttive: This research will describe the characteristics of patients with low risk GTN with chemoresistancy to methotrexate at Hasan Sadikin Hospital Bandung during the period 2011-2015.

Method: This research was a descriptive retrospective study located at Obstetrics and Gynecology Department and Medical Record Installation of Hasan Sadikin Hospital Bandung from April to May 2017.

Results: During research period that was 46 low risk GTN cases with chemoresistancy to methotrexate. Number of incident mostly in 31-35 years (45,6\%), 36,9\% with parity 2, 69,6\% with clinical symptom of abnormal vaginal bleeding, 91,3\% with previous pregnancy hydadityform mole, 52,5\% had interval between pregnancy with GTN diagnose was $\leq 4$ months, $60,9 \%$ with intial $\beta$ - $h C G>100.000 \mathrm{mIU} / \mathrm{ml}, 28,3 \%$ case metastasized, 76,9\% in lung and $23 \%$ in brain. Most of the GTN cases found in stage I (65,2\%), in stage II, III and IV was 10,9\%, 15,2\% and 8,7\%. Discussion: Chemoresistancy to methotrexate in low risk GTN mostly occur in 31-35 years of age, parity 2, mostly clinical symptom of abnormal vaginal bleeding, hidatydiform mole previous pregnancy, interval between pregnancy was $\leq 4$ months, intial $\beta$-hCG $>100.000 \mathrm{mIU} / \mathrm{ml}$, and mostly found in first stage.
\end{abstract}

Key words: Low risk gestational thropoblastic neoplasiac, hemoresistant 


\section{Pendahuluan}

Tumor trofoblas gestasional (TTG) adalah suatu bentuk degenerasi keganasan pada mola hidatidosa yang disebabkan proliferasi sel trofoblas secara abnormal yang berlangsung terus-menerus. ${ }^{1}$ Insidensi TTG di negara maju adalah 1 dari 40.000 kehamilan, sementara di Asia Tenggara mencapai 9,2 dari 40.000 kehamilan. $^{2,3}$

Faktor-faktor yang mempengaruhi perkembangan TTG pasca mola, yaitu: usia, kadar hCG preevakuasi yang tinggi, ukuran uterus yang lebih besar dari usia kehamilan, dan adanya kista teka lutein. ${ }^{4}$

Diagnosis TTG secara klinis yaitu adanya keluhan perdarahan pervaginam dan rahim subinvolusi; secara histopatologis didapatkan gambaran mola invasif, koriokarsinoma, dan placental site of trophoblastic tumour; dan dari pemeriksaan laboratorium didapatkan kadar $\beta$-hCG meningkat kembali dalam 4 minggu pasca evakuasi, kadar $\beta$-hCG mencapai $>100 \mathrm{mIU} / \mathrm{ml} 6 \mathrm{minggu}$ pasca evakuasi, atau kadar $\beta$-hCG mencapai $>30$ $\mathrm{mIU} / \mathrm{ml} 8$ minggu pasca evakuasi. TTG dibagi menjadi dua kelompok berdasarkan sistem skoring prognostik yang dibuat oleh FIGO, yaitu skor 0-6 memiliki risiko rendah dan diterapi dengan agen kemoterapi tunggal, sedangkan skor $\geq 7$ memiliki risiko tinggi dan memerlukan kemoterapi kombinasi. ${ }^{5}$ TTG sangat sensitif terhadap kemoterapi dan memiliki angka remisi yang tinggi, dengan angka resistensi terhadap kemoterapi sebanyak 3\% pada TTG risiko rendah dan $7-10 \%$ pada TTG risiko tinggi. ${ }^{6}$

Definisi kemoresisten adalah peningkatan kadar $\beta$-hCG 20\% setelah dilakukan pengukuran dua kali atau terjadi plateau atau penurunan kadar $\beta$-hCG $<90 \%$ setelah dilakukan pengukuran setelah tiga minggu. ${ }^{7}$ Penelitian yang dilakukan oleh Hemida dkk. menyatakan terdapat $15,15 \%$ kasus kemoresisten pada TTG risiko rendah dan $60 \%$ pada TTG risiko tinggi. ${ }^{8}$ Berdasarkan penelitian yang dilakukan oleh Taylor dkk., pasien TTG risiko rendah dengan kadar $\beta$-hCG awal $>100.000 \mathrm{mIU} / \mathrm{ml}$ secara signifikan memiliki risiko lebih tinggi (84\%) terjadinya kemoresisten dibandingkan dengan pasien dengan kadar $\beta$-hCG awal $<100.000 \mathrm{mIU} / \mathrm{ml}(34 \%) .{ }^{9}$ TTG yang resisten terhadap kemoterapi memiliki beberapa komplikasi yaitu perdarahan dari satu atau lebih daerah metastasis, gagal nafas, dan kegagalan multi organ yang disebabkan terjadinya kemoresistensi yang berujung pada kematian ${ }^{10,11}$

Rumusan masalah penelitian ini adalah bagaimana karakteristik pasien TTG risiko rendah yang kemoresisten terhadap metotreksat di Rumah Sakit Hasan Sadikin Bandung periode Januari 2011 sampai Desember 2016 berdasarkan umur, paritas, gejala klinis, riwayat kehamilan sebelumnya, jarak kehamilan sebelumnya, kadar $\beta$-hCG, lokasi metastasis, dan stadium.

Tujuan penelitian adalah untuk mengetahui karakteristik pasien TTG risiko rendah yang kemoresisten terhadap metotreksat di Rumah Sakit Hasan Sadikin Bandung periode Januari 2011 sampai Desember 2016 berdasarkan umur, paritas, gejala klinis, riwayat kehamilan sebelumnya, jarak kehamilan sebelumnya, kadar $\beta$-hCG, lokasi metastasis, dan stadium.

\section{Metode}

Penelitian ini adalah penelitian desktriptif retrospektif. Kegiatan penelitian dilakukan di Departemen/SMF Obstetri dan Ginekologi Fakultas Kedokteran Universitas Padjadjaran Rumah Sakit Umum Pusat Hasan Sadikin Bandung dengan sumber data diperoleh dari Instalasi Rekam Medik Rumah Sakit Hasan Sadikin Bandung. Penelitian dilakukan pada bulan April sampai Mei 2017. Populasi target penelitian adalah semua pasien Tumor Trofoblas Gestasional (TTG) risiko rendah dengan kemoresistensi terhadap metotreksat 
yang berobat ke Rumah Sakit Hasan Sadikin Bandung. Populasi terjangkau penelitian adalah semua pasien TTG risiko rendah dengan kemoresistensi terhadap metotreksat yang berobat ke Rumah Sakit Hasan Sadikin Bandung dari bulan Januari 2011 sampai Desember 2016. Sampel penelitian ini adalah semua pasien TTG risiko rendah dengan kemoresistensi terhadap metotreksat yang berobat ke Rumah Sakit Hasan Sadikin Bandung dari bulan Januari 2011 sampai Desember 2016 serta memenuhi kriteria inklusi dan eksklusi penelitian.

Kriteria inklusinya adalah sebagai berikut:

a. Wanita dengan tumor trofoblas gestasional risiko rendah berdasarkan sistem skoring FIGO

b. Mendapatkan pengobatan kemoterapi metotreksat $50 \mathrm{mg}$ intramuskuler

c. Pasien tumor trofoblas gestasional risiko rendah yang resisten terhadap kemoterapi metotreksat $50 \mathrm{mg}$ intramuskuler

d. Pasien dengan data rekam medis yang dapat ditemukan

e. Pasien dengan data rekam medis yang lengkap

Kriteria eksklusinya adalah

a. Pasien meninggal selama pengobatan

b. Pasien tidak menyelesaikan pengobatan

c. Data rekam medis pasien yang hilang atau tidak terisi lengkap

Definisi Operasional Variabel

1. Umur adalah usia pasien dalam tahun yang diperoleh dari rekam medis pasien.

2. Paritas adalah jumlah janin viabel yang dilahirkan, diperoleh dari rekam medis pasien.

3. Gejala klinis adalah keluhan utama pasien saat berobat pertama kali ke poliklinik Obstetri dan Ginekologi Rumah Sakit Hasan Sadikin Bandung, diperoleh dari rekam medis pasien.

4. Riwayat kehamilan sebelumnya adalah kehamilan terakhir yang dialami oleh pasien meliputi kehamilan aterm, abortus, atau mola hidatidosa yang diperoleh dari rekam medis.

5. Jarak kehamilan sebelumnya adalah lama dalam bulan antara kehamilan sebelumnya dengan pasien pertama kali datang ke poliklinik Obstetri dan Ginekologi Rumah Sakit Hasan Sadikin Bandung yang diperoleh dari rekam medis.

6. Kadar $\beta$-HCG adalah jumlah kuantitatif dari $\beta$-HCG dalam $\mathrm{mIU} / \mathrm{ml}$ yang dikelompokkan menjadi empat, yaitu $<10^{3}, 10^{3}-10^{4}, 10^{4}-10^{5}$, dan $>10^{5}$ yang diperoleh dari rekam medis pasien.

7. Lokasi metastasis adalah tempat penyebaran dari Tumor Trofoblas Gestasional (TTG) yang diperoleh dari data rekam medis pasien.

8. Stadium Tumor Trofoblas Gestasional (TTG) adalah derajat beratnya TTG menurut International Federation of Gynecology and Obstetrics (FIGO) berdasarkan hasil evaluasi di Poliklinik Obstetri dan Ginekologi yang diperoleh dari data rekam medis pasien.

Bahan dan instrument penelitian adalah rekam medis pasien TTG risiko rendah dengan kemoresistensi terhadap metotreksat di Rumah Saki Hasan Sadikin Bandung dari Januari 2011 sampai Desember 2016. Alur penelitian mengikuti tahapan sebagai berikut:

Data hasil penelitian yang diperoleh dari Rekam Medis dikumpulkan dan dimasukkan ke dalam formulir penelitian. Data yang diperoleh pada penelitian adalah data desktriptif sehingga dilakukan analisis data secara desktriptif dengan menggunakan software SPSS for windows yang ditampilkan dalam bentuk tabel.

\section{Hasil}

Pada penelitian ini ditemukan 240 kasus Tumor Trofoblas Gestasional (TTG) yang terdiri dari $187(77,9 \%)$ kasus risiko rendah dan $53(22,1 \%)$ kasus risiko tinggi yang 


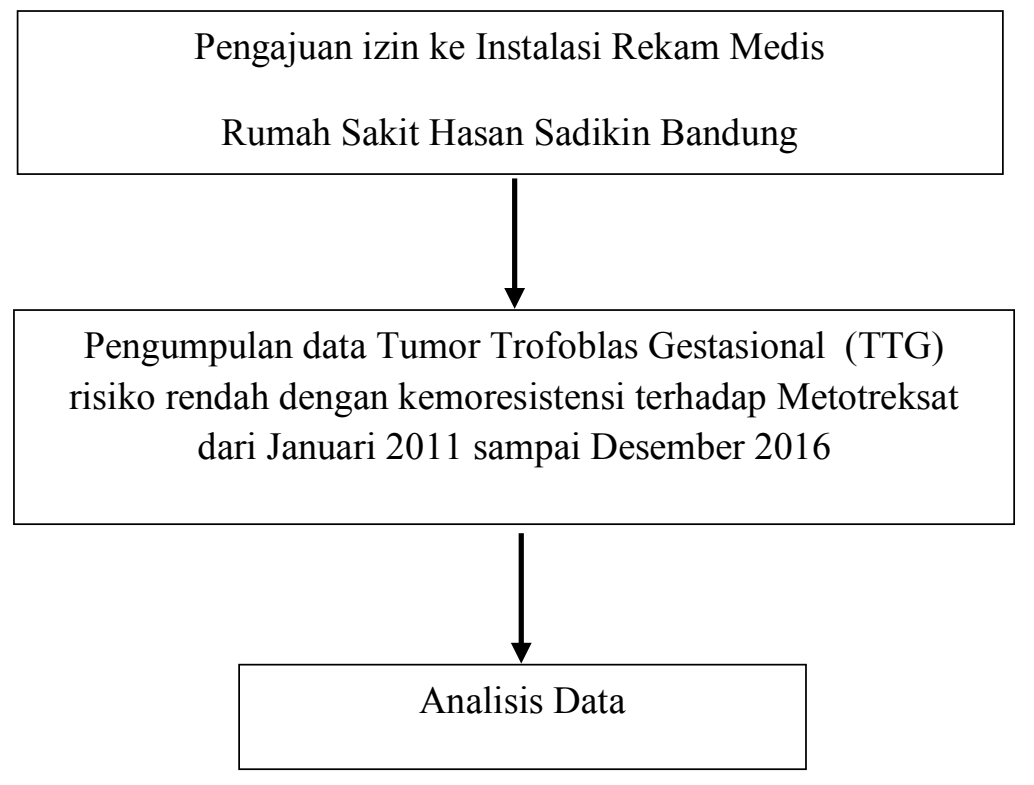

Penulisan Laporan Penelitian

Gambar 1 Alur Penelitian

berobat ke RS Hasan Sadikin Bandung sejak Januari 2011 sampai Desember 2016. Sedangkan, dari 187 kasus TTG risiko rendah, terdapat $46(24,6 \%)$ kasus yang mengalami resistensi terhadap metotreksat. Adapun karakteristik penderita tersebut dapat dilihat pada tabel 3.1. Rentang usia yang terbanyak pada kasus TTG risiko rendah dengan resistensi terhadap metotreksat adalah 31-40 tahun, yaitu 71,7\%. Sedangkan, berdasarkan paritas, tidak terdapat perbedaan yang besar pada jumlah kasus TTG risiko rendah dengan resistensi metotreksat. Pada penelitian ini, $69,6 \%$ kasus mengalami perdarahan sebagai manifestasi klinis TTG risiko rendah dengan resistensi metotreksat dan tidak ada yang mengalami nyeri perut.

\section{Tabel 1 Karakteristik Pasien Tumor Trofoblas Gestasional Risiko Rendah dengan Kemoresistensi terhadap Metotreksat di Rumah Sakit Hasan Sadikin Bandung tahun 2011-2016}

\begin{tabular}{lcc}
\hline \multicolumn{1}{c}{ Karakteristik } & $\begin{array}{c}\text { Frekuensi } \\
(\mathbf{n})\end{array}$ & $\begin{array}{c}\text { Persentase } \\
(\%)\end{array}$ \\
\hline Umur & & \\
$\leq 20$ & 2 & 4,3 \\
$21-25$ & 0 & 0 \\
$26-30$ & 6 & 13,0 \\
$31-35$ & 21 & 45,6 \\
$36-40$ & 12 & 26,1 \\
$41-45$ & 0 & 0 \\
$>45$ & 5 & 10,9 \\
Paritas & & \\
0 & 9 & 19,6 \\
1 & 12 & 26,1 \\
2 & 17 & 36,9 \\
3 & 3 & 6,5 \\
$\geq 4$ & 5 & 10,9
\end{tabular}




\section{Lanjutan Tabel 1 Karakteristik Pasien Tumor Trofoblas Gestasional Risiko Rendah dengan Kemoresistensi terhadap Metotreksat di RSUP Dr. Hasan Sadikin Bandung tahun 2011-2016}

\begin{tabular}{|c|c|c|}
\hline Karakteristik & $\begin{array}{c}\text { Frekuensi } \\
\text { (n) }\end{array}$ & $\begin{array}{c}\text { Persentase } \\
(\%)\end{array}$ \\
\hline \multicolumn{3}{|l|}{ Gejala Klinis } \\
\hline Perdarahan & 32 & 69,6 \\
\hline Perut membesar & 14 & 30,4 \\
\hline Nyeri perut & 0 & 0 \\
\hline \multicolumn{3}{|l|}{$\begin{array}{l}\text { Riwayat Kehami- } \\
\text { lan Sebelumnya }\end{array}$} \\
\hline Mola hidatidosa & 42 & 91,3 \\
\hline Abortus & 4 & 8,7 \\
\hline Hamil aterm & 0 & 0 \\
\hline \multicolumn{3}{|l|}{$\begin{array}{l}\text { Jarak kehamilan } \\
\text { sebelumnya } \\
\text { (bulan) }\end{array}$} \\
\hline$\leq 4$ & 24 & 52,5 \\
\hline $4-6$ & 12 & 26,1 \\
\hline $7-12$ & 4 & 8,7 \\
\hline$\geq 12$ & 6 & 13,0 \\
\hline \multicolumn{3}{|l|}{$\begin{array}{l}\text { Kadar } \beta \text {-HCG } \\
(\mathrm{mIU} / \mathrm{ml})\end{array}$} \\
\hline$\leq 10^{3}$ & 0 & 0 \\
\hline $10^{3}-10^{4}$ & 10 & 21,7 \\
\hline $10^{4}-10^{5}$ & 8 & 17,4 \\
\hline$>10^{5}$ & 28 & 60,9 \\
\hline
\end{tabular}

Pada riwayat kehamilan sebelumnya, 91,3\% mengalami mola hidatidosa dan $8,7 \%$ mengalami abortus. Tidak ada yang mengalami kehamilan aterm sebelumnya. Kasus pada penelitian ini yang memiliki jarak $\leq 4$ dan $>4$ bulan dengan kehamilan sebelumnya memiliki proporsi yang sama.
Tabel 2 Karakteristik Pasien Tumor Trofoblas Gestasional Risiko Rendah dengan Kemoresistensi terhadap Metotreksat di Rumah Sakit Hasan Sadikin Bandung tahun 2011-2016

\begin{tabular}{lcc}
\hline \multicolumn{1}{c}{ Karakteristik } & $\begin{array}{c}\text { Frekuensi } \\
\text { (n) }\end{array}$ & $\begin{array}{c}\text { Persentase } \\
(\mathbf{\%})\end{array}$ \\
\hline Metastasis Tumor & & \\
Tidak ada & 33 & 71,7 \\
Ada & 13 & 28,3 \\
$\quad$ Paru-paru & 10 & 76,9 \\
$\quad$ Otak & 3 & 23,0 \\
Stadium & & \\
I & 30 & 65,2 \\
II & 5 & 10,9 \\
III & 7 & 15,2 \\
IV & 4 & 8,7 \\
\hline
\end{tabular}

Selain itu, sebagian besar $(60,9 \%)$ memiliki kadar $\beta$-HCG $>10^{5} \mathrm{mIU} / \mathrm{ml}$. Kasus yang tidak mengalami metastasis lebih banyak dibandingkan dengan yang mengalami metastasis, yaitu masing-masing, 71,7\% dan 28,3\%. Metastasis terbanyak adalah metastasis ke paru-paru, yaitu $76,9 \%$ dari seluruh kasus yang mengalami metastasis. Kasus TTG risiko rendah stadium I $(65,2 \%)$ merupakan yang paling banyak mengalami resistensi terhadap metotreksat dibandingkan dengan stadium lainnya.

\section{Pembahasan}

TTG risiko rendah lebih banyak ditemukan dibandingkan dengan TTG risiko tinggi. Hal ini disebutkan juga pada suatu penelitian retrospektif yang mengikutsertakan 51 kasus TTG, yaitu 70,6\% di antaranya merupakan TTG risiko rendah. ${ }^{8}$ Penelitian lain di Sheffield Center melaporkan juga bahwa jumlah pasien TTG risiko rendah dibandingkan dengan TTG risiko tinggi adalah 392 dan 66 pasien. ${ }^{12}$ Selain itu, 24,6\% dari kasus TTG risiko rendah mengalami resistensi terhadap metotreksat. Insidensi tersebut sesuai dengan 
yang disebutkan dalam beberapa penelitian, yaitu $15,9-35,7 \% .{ }^{12-14}$ Sedangkan penelitian pada Western Park Hospital dan Charing Cross Hospital, melaporkan kasus resistensi yang mencapai $40-42 \%$ dari total kasus TTG risiko rendah., ${ }^{9,15}$ Jumlah kasus terbanyak pada penelitian ini ditemukan pada rentang usia 31-40 tahun, sama halnya dengan yang dilaporkan oleh beberapa penelitian lain. ${ }^{16-}$ ${ }_{18}$ Beberapa penelitian lainnya menyatakan bahwa usia yang sering mengalami kasus ini adalah di bawah 31 tahun. ${ }^{8,19}$ Akan tetapi, suatu penelitian di menyatakan bahwa usia tidak memiliki hubungan yang signifikan dengan kejadian resistensi terhadap metotreksat. Perbedaan ini disebabkan oleh adanya perbedaan dalam kriteria komunitas yang diikutsertakan ke dalam masing-masing penelitian. ${ }^{19}$

Pada penelitian ini, tidak terdapat perbedaan yang banyak pada jumlah kasus berdasarkan jumlah paritas. Hal serupa dilaporkan pada penelitian di Iran dan Mesir, yaitu tidak ada hubungan yang signifikan antara jumlah paritas dengan kejadian resistensi terhadap metotreksat. ${ }^{8}$ ${ }_{17}$ Manifestasi klinis perdarahan merupakan yang terbanyak ditemukan pada penelitian ini dan sesuai dengan penelitian lain, yaitu masing-masing, $69,6 \%$ dan $78,4 \%{ }^{8}$

Berdasarkan riwayat kehamilan sebelumnya, penelitian ini sesuai dengan beberapa penelitian lain, yaitu dengan urutan dari yang terbanyak ialah riwayat mola hidatidosa dan aborsi, serta yang paling sedikit ialah riwayat kehamilan aterm. Salah satu di antara penelitian tersebut melaporkan adanya hubungan yang signifikan antara riwayat mola hidatidosa, aborsi dan kehamilan aterm dengan kasus TTG risiko rendah dengan resistensi terhadap metotreksat. ${ }^{8,12,16}$ Walaupun begitu, penelitian yang dilakukan di Iran dan Senegal menyatakan bahwa riwayat pada kehamilan sebelumnya tidak memiliki hubungan yang signifikan dengan kejadian resistensi pada kasus tersebut. ${ }^{13,19}$
Proporsi yang sama pada kasus TTG risiko rendah yang resisten terhadap metotreksat dengan jarak $\leq 4$ bulan dan $>4$ bulan dengan kehamilan sebelumnya juga ditemukan pada penelitian lain. ${ }^{13,19}$ Sebagian besar kasus pada penelitian ini memiliki kadar $\beta$-HCG $>10^{5} \mathrm{mIU} / \mathrm{ml}$, sesuai dengan beberapa penelitian lain. ${ }^{8-10,19,20}$ Bahkan sebuah penelitian menyatakan bahwa kadar $\beta$-HCG $>10^{5} \mathrm{mIU} / \mathrm{ml}$ dapat meningkatkan risiko terjadinya resistensi terhadap metotreksat secara signifikan., 10, 12, 19-21 Di sisi lain, terdapat dua penelitian melaporkan hal yang sebaliknya. ${ }^{13,18}$

Metastasis terjadi pada $28,3 \%$ dari total kasus pada penelitian ini. Sebuah penelitian lain melaporkan $21 \%$ dari kasus tersebut mengalami metastasis. ${ }^{16}$ Sedangkan, dua penelitian lainnya melaporkan lebih dari 50\% dari kasus tersebut mengalami metastasis dan menyatakan bahwa terdapat peningkatan risiko resistensi terhadap metotreksat hingga 8 kali lipat dengan adanya metastasis pada kasus TTG risiko rendah. ${ }^{8,} 19$ Akan tetapi, penelitian-penelitian tersebut melaporkan bahwa metastasis yang terbanyak adalah metastasis ke paru-paru, sesuai dengan yang dilaporkan pada penelitian ini. ${ }^{8,16}$

Sebagian besar kasus TTG risiko rendah dengan resistensi terhadap metotreksat merupakan stadium I. Hal tersebut didukung oleh hasil penelitian yang dilaporkan pada beberapa penelitian lain. Walaupun begitu, penelitian tersebut menyatakan tidak adanya hubungan yang signifikan antara stadium penyakit dengan kejadian resistensi terhadap metrotreksat pada kasus ini. ${ }^{13,}{ }^{18}$ Simpulan, semoresistensi terhadap metotreksat pada TTG risiko rendah paling banyak muncul pada usia 31-35 tahun, dengan paritas 2, gejala klinis paling banyak adalah perdarahan pervaginam, dengan jenis kehamilan sebelumnya adalah mola hidatidosa, interval kehamilan sebelumnya $\leq 4$ bulan, dan kadar $\beta$-hCG inisial adalah $>100.000 \mathrm{mIU} / \mathrm{ml}$, dan paling banyak adalah stadium I. 


\section{Daftar Pustaka}

1. Niemann I, Vejerslev LO, Frøding L, Blaakær J, Maroun LL, Hansen ES, et al. Gestational trophoblastic diseases clinical guidelines for diagnosis, treatment, follow up, and counselling. Danish Med J. 2015;62(11).

2. Lurain JR. Gestational trophoblastic disease I: epidemiology, pathology, clinical presentation and diagnosis of gestational trophoblastic disease, and management of hydatidiform mole. Am J Obstet Gynecol. 2010;203(6):531-9.

3. Martaadisoebrata D. Protokol pengelolaan penyakit trofoblas gestasional.Edisi ke 1. Bandung: Pusat Pengelolaan Penyakit Trofoblas Gestasional; 2005.

4. Lorigan P, Sharma S, Bright N, Coleman R, Hancock B. Characteristics of women with recurrent molar pregnancies. Gynecol Oncol. 2000;78(3):288-92.

5. Hancock B, Welch E, Gillespie A, Newlands E. A retrospective comparison of current and proposed staging and scoring systems for persistent gestational trophoblastic disease. Int J Gynecol Cancer. 2000;10(4):318-22.

6. Lybol C, Sweep FC, Ottevanger PB, Massuger LF, Thomas CM. Linear regression of postevacuation serum human chorionic gonadotropin concentrations predicts postmolar gestational trophoblastic neoplasia. Int $\mathrm{J}$ Gynecol Cancer. 2013;23(6):1150-6.

7. Lobo RA, Gershenson DM, Lentz GM, Valea FA. Comprehensive gynecology. Edisi ke 7. Oxford: Elsevier; 2017.

8. Hemida RAE, Toson E, Shalaby H, Refaie E, Eldin DS. Chemo-resistant gestational trophoblastic neoplasia, 5-years experience of mansoura university hospital, egypt. OJOG. 2011;1:153-7.

9. Taylor F GT, Everard J, Ellis L, Winter
MC, Tidy J, Hancock BW, Coleman RE. The outcome of patients with low risk gestational trophoblastic neoplasia treated with single agent intramuscular methotrexate and oral folinic acid. European J Cancer. 2013;49(15):318490.

10. Ngu S-F, Chan KK. Management of chemoresistant and quiescent gestational trophoblastic disease. Current Obstet Gynecol. 2014;3(1):84-90.

11. Neubauer NL, Strohl AE, Schink JC, Lurain JR. Fatal gestational trophoblastic neoplasia: An analysis of treatment failures at the Brewer Trophoblastic Disease Center from 1979-2012 compared to 1962-1978. Gynecol oncol. 2015;138(2):339-42.

12. Strohl A, Lurain J. Postmolar choriocarcinoma: An independent risk factor for chemotherapy resistance in low-risk gestational trophoblastic neoplasia. Gynecol Oncol. 2016:1-5.

13. Gueye M, Gueye M, Gueye S, Dia F, Thiam A, Diouf S, et al. Efficacy and Risk Factors Associated to Resistance to Single-Agent Chemotherapy in Low-Risk Gestational Trophoblastic Neoplasia. Open J Obs Gynecol. 2016;6:50-5.

14. Winter M, Tidy J, Hills A, Ireson J, Gillett $\mathrm{S}$, Singh $\mathrm{K}$, et al. Risk adapted singleagent dactinomycin or carboplatin for second-line treatment of methotrexate resistant low-risk gestational trophoblastic neoplasia. Gynecol Oncol. 2016:1-6.

15. You B, Harvey R, Mitchell H, Golfier F, Savage P, Tod M, et al. Early prediction of treatment resistance in low-risk gestational trophoblastic neoplasia using population kinetic modelling of hCG measurements. Brit $\mathrm{J}$ of Can. 2013;108:1810-6.

16. Feng $F$, Xiang $Y$, Wan $X$, Zhou Y. Prognosis of patients with relapsed and 
chemoresistant gestational trophoblastic neoplasia transferred to the Peking Union Medical College Hospital. BJOG. 2010;117:47-52.

17. Gillani M, Fariba B, Behtash N, Gaemmaghami F, Moosavi A, Rezayof E. The WHO score predicts treatment outcome in low risk gestational trophoblastic neoplasia patients treated with weekly intramuscular methotrexate. J Can Res Ther. 2013;9(1):38-43.

18. Byun S, Park T, Bae S. Conservative Chemotherapy in Gestational Trophoblastic Disease Experience With Etoposide, Methotrexate, and Dactinomycin Chemotherapy. Int $\mathrm{J}$ Gynecol Cancer. 2016;26(4):790-5.

19. Mousavi AS, Zamani A, Khorasanizadeh F, Gilani MM, Zendehdel K. Resistance to single-agent chemotherapy and its risk factors in low-risk gestational trophoblastic neoplasms. J Obstet Gynecol Res. 2015;41(5):776-83.

20. Lybol C, Sweep FC, Harvey R, Mitchell H, Short D, Thomas CM, et al. Relapse rates after two versus three consolidation courses of methotrexate in the treatment of low-risk gestational trophoblastic neoplasia. Gynecol Oncol. 2012;125(3):576-9.

21. Laul P SP, Kadam VK, Miglani U. Two interesting cases of gestational trophoblastic disease with methotrexate failure. Int J Reprod Contracept Obstet Gynecol.; 2016. p. 3251-3. 